\title{
PENGARUH JENIS PENYEKORAN PEROLEHAN TES PILIHAN GANDA PADA STRATEGI PEMBELAJARAN KOOPERATIF TERHADAP HASIL BELAJAR KIMIA DALAM TOPIK LAJU REAKSI
}

Asma Farida

Pensiunan guru Kimia SMK N 26 Jakarta

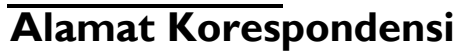 \\ J.Ternate no $116 \mathrm{~A}$ \\ Jakarta 10150 \\ Tlp 0216324062 \\ asmaf226@gmail.com
}

\begin{abstract}
This study investigated: a) Interaction effect between cooperative learning strategy and type of scoring, b) Main effect of cooperative learning strategy, c) Main effect of scoring types, and d) Simple effects of learning model toward type of scoring. The target population 923 comprised all students whose learning chemistry and 52 students grades XI were selected as a convenient sample of the study in SMKN 26 Jakarta. This study was carried out in four differents classes during October-November 2016. The instrument for obtaining data was Chemical Kinetics Achievement Test (CKAT), another six Chemical Kinetics Achievement test as formative tes were applied to the treatments groups. Both of them developed by writer. Two way of varians (ANAVA) was used to analyze the data. Post hoc comparisons using one way of Analysis of Varians (ANOVA) also used to examine there were differentiated among the four of treatment group. The findings suggest that there was no difference between using cooperative learning strategy jigsaw and STAD on students' chemistry achievement.There was difference between two types of scoring, corrected score (CS) and number right score (NRS) in student' chemistry achievement., CS higher than NRS. There was the interaction effects of treatment using cooperative learning strategy and types of scoring, it was mean the types of scoring efective depend on technique of cooperatif learning strategy, CS more effective to NRS if we use jigsaw while NRS more efective to CS if we use STAD.
\end{abstract}

\section{Keywords}

Types of scoring, multiple-choice test (MCT), cooperative learning strategy

\section{ABSTRAK}

Penelitian ini bertujuan untuk menentukan: a) pengaruh interaksi strategi pembelajaran kooperatif dan jenis penyekoran, b) pengaruh utama antara dua model strategi pembelajaran kooperatif, c) pengaruh utama antara dua jenis penyekoran, dan d) pengaruh sederhana dari model pembelajaran terhadap jenis penilaian. Populasi target 923 siswa yang belajar kimia dan sebagai sampel adalah 52 siswa kelas XI yang terseleksi sesuai dengan penelitian ini di SMKN 26 Jakarta. Penelitian ini terbagi dalam 4 kelompok perlakuan yang berbeda selama bulan Oktober-November 2016. Untuk pengumpulan data digunakan instrumen 40 item tes laju reaksi (TLR) 6 tes laju reaksi yang lainnya merupakan tes formatif yang digunakan sebagai perlakuan pada tiap kelompok. Keduanya dikembangkan oleh penulis. Analisis variansi dua jalan (ANAVA) digunakan untuk menganalisa data. Post hoc comparison menggunakan analisis variansi satu jalan juga digunakan untuk menguji adanya perbedaan di antara ke empat kelompok perlakuan. Temuan utama dari penelitian ini adalah: Tidak ada perbedaan antara Jigsaw dan STAD pada hasil belajar kimia siswa. Ada perbedaan hasil belajar kimia siswa pada dua jenis penyekoran corrected score (CS) dan number right score (NRS). Hasil belajar kimia kelompok siswa yang tes formatifnya disekor dengan CS lebih tinggi daripada yang disekor dengan NRS. Ada pengaruh interaksi antara model pembelajaran kooperatif dan jenis penyekoran tes pilihan ganda, artinya efektifitas jenis penyekoran tergantung pada teknik strategi pembelajaran kooperatif, CS lebih efektif jika menggunakan Jigsaw dan NRS lebih efektif jika menggunakan STAD.

Kata Kunci

jenis penyekoran, pilihan ganda (PG), strategi pembelajaran kooperatif. 


\section{Pendahuluan}

Kurikulum 20I3 dikembangkan berdasarkan di antaranya faktor tantangan eksternal antara lain terkait arus globalisasi dan berbagai isu terkait dengan masalah lingkungan hidup, kemajuan teknologi dan informasi, dan perkembangan pendidikan di tingkat internasional. Keikutsertaan Indonesia di dalam studi internasional Trends International Mathematics and Science Study (TIMSS) dan Program For International Student Assessment (PISA) sejak tahun 1999 menunjukkan bahwa capaian anak-anak Indonesia tidak menggembirakan dalam beberapa kali laporan yang dikeluarkan oleh TIMSS dan PISA (struktur kurikulum SMK pasal I ayat 2). Indonesia mengikuti PISA sejak tahun 2000 sampai dengan tahun 2015. Rata-rata sekor yang diperoleh Indonesia pada PISA tahun 2015 adalah 403 sementara rata-rata OECD adalah 493 (Science Literacy Average Score, PISA 2015). Pada TIMSS 20II Indonesia berada di urutan ke 2 dari bawah dengan perolehan 19, sementara capaian tertinggi 87 dan terendah 6 (Performance at TIMSS 20II). Dalam kurikulum pada pasal 6: Bidang Kejuruan Teknologi dan Rekayasa sebagaimana yang dimaksud dalam pasal 5 ayat 12 huruf a. Terdapat mata pelajaran kimia. Pada kompetensi dasar mata pelajaran kimia bagi siswa kelas XI terdapat topik laju reaksi yang terdiri dari mengevaluasi terjadinya reaksi kimia dengan menggunakan teori tumbukan (tabrakan) dan membuktikan proses laju reaksi dari berbagai faktor yang mempengaruhinya (kurikulum, 20I3 SMK/MAK). Pelajaran kimia di SMK diharapkan dapat berkontribusi pada Science Technology Engineering and Mathematics (STEM) yang saat ini hangat diperbincangkan. Hal ini akan menambah softskill pada siswa kejuruan teknologi dan rekayasa. Laju reaksi penting pada proses kimia di Industri, medical, dan lingkungan (Justi, 2003). Kimia kinetik memberi pemahaman cara reaksi kimia berproses. Mengobservasi hubungan antara laju reaksi dan variabel yang mempengaruhinya serta mekanisme reaksi yang dapat menjelaskan secara eksperimen penentuan hukum laju reaksi (Heck, 20I2). Pada PISA yang dirilis tahun 2000 menyinggung tentang lapisan ozon yang diakibatkan oleh CFC. Seperti diketahui CFC berkaitan erat dengan katalis yang merupakan salah satu faktor yang mempengaruhi laju reaksi. Soal berikutnya adalah penggunaan katalis konverter; menanyakan masalah apa yang menyebabkan enginering dan saintis bekerja pada katalis konverter (PISA Released Items-Science, December 2006). Pada TIMSS yang dirilis tahun 1999 menanyakan mengenai mengapa balok terbakar lebih lambat dibadingkan dengan balok yang telah dipotong-potong kecil. Laju reaksi dipengaruhi oleh salah-satunya adalah luas permukaan sentuh. Pada level sekolah menengah dan level yang lebih tinggi, laju reaksi dianggap topik yang sulit untuk diajarkan oleh guru dan dipelajari oleh siswa. (Justi, 2003; Chairam \& Klahan, 2009; Kirik \& Boz, 20I2). Kimia kinetik merupakan topik yang sulit untuk diajarkan dan dipelajari apakah itu secara kuantitatif maupun secara kualitatif (Hek, 20I2). Calon guru kimia Turki kesulitan mempelajari kimia kinetik (Tastan et al, 20l0). Guru kimia Turki memiliki konsep yang salah tentang laju reaksi (Kolomuç \& Tekin, 20II). Pengajaran kimia kinetik seringkali didominasi oleh guru baik di sekolah menengah maupun di tingkat yang lebih tinggi (Chairman et al, 2009). Siswa memiliki konsep yang sulit pada dasar kimia kinetik dan thermodinamik (Sozbilir, 2009). Kimia kinetik dipandang sulit oleh siswa sekolah menengah dan mahasiswa (Van Driel, 2002; Cakmakci, Leach, Donnelelly, 2006) Di River State Nigeria pada item analisis pada penghitungan laju reaksi hanya $10 \%$ siswa yang dapat mengidentifikasi jawaban benar dan 90\% salah. (Macson J. Ahiakwo and Chigozirim Q. Isiguzo, 20I5). Siswa sekolah menengah mengalami kecemasan yang tinggi dan mereka tidak tertarik untuk menggambar dan menginterpretasikan grafik (Nigün Seçken dan Hatice Günjör Seyhan, 20I5). Siswa dapat menjawab dengan benar jika data diberikan dalam bentuk tabel daripada dalam bentuk grafik (Bektasli and Cakmakci, 20II) Penelitian yang dilakukan di SMAN I Sanggau Ledo menunjukkan bahwa tingkat kesulitan peserta didik dalam memahami materi, laju reaksi adalah $80,31 \%$ 
(sangat tinggi) (Franciska Rica dan Suyanta, 20I3). Penyebab kesulitan belajar siswa pada mata pelajaran kimia di antaranya metode belajar $\mathbf{7 7 \%}$ (kategori tinggi) dan guru 77,17\% (kategori tinggi) (Erika Ristiyanti dan Evi Sapinatul Bahriah, 20I4). Menurut Hewson and Hewson (1983) Kesulitan dalam memahami konsep saintifik berakar dari kesalah-pahaman yang dibawa siswa ke dalam kelas sebelum instruksi (Kaya and Geban, 20I2).

Salah satu penyebab dari kecemasan siswa terhadap kimia adalah guru dan kurangnya metode serta alat bantu mengajar (laboratorium). (Jegede, 2007: 193-197). Menurut Usman dan Memeh Kurangnya minat atau sikap negatif terhadap kimia; guru, yang berhubungan dengan kurangnya persiapan guru; kualifikasi guru kimia yang tidak memadai, instruksional materi yang tidak memadai dan pengaplikasian metoda mengajar yang rendah (Nbina, Jacobson Barineka, B. Vitco, 2010: 38). Penelitian mengungkapkan pengajaran kimia tidak mempromosikan higher order cognitive skills (Anderson et al, 1992; Zohler, 1993)

Sozbilir menyarankan untuk menggunakan penelitian yang mengembangkan strategi mengajar dalam mengatasi kesulitan pada kimia kinetik (Sozbilir, 20l0). Kelompok yang menggunakan pembelajaran kooperatif memperlihatkan perolehan pengetahuan laju reaksi lebih baik daripada kelompok tradisional pada kedua sekolah (Kirik \& Boz, 20I2).

Mengajar adalah proses di mana guru menggunakan instruksinya untuk membantu siswa meraih tujuan belajarnya. (Nitco, 200 I: 22). Pada beberapa penelitian menunjukkan kurangnya pengetahuan dasar kimia pada guru pada semua level. (Onno De Jong , 2003: 365). Konsep pengetahuan guru dibagi menjadi dua aspek yang penting, pengetahuan subjek materi guru dan pengetahuan pedagogik guru (De Jong, 2003: 365). Penelitian pada pemikiran guru, berhubungan erat antara apa yang guru pikirkan dan bagaimana mereka mengajar. Hubungan ini memiliki karakteristik timbal balik. Pengetahuan guru berdasar pada perencanaan pengajaran dan praktik kelas, sebaliknya aktivitas mengajar mempengaruhi dasar pengetahuannya (De Jong,
2003). Banyak literatur merekomendasikan untuk mengarahkan pengajaran kimia umumnya dan kimia kinetik khususnya yang didominasi guru yang sifatnya pasif untuk bergerak ke arah belajar berpusat pada siswa yang sifatnya aktif. Perencanaan pengajaran diawali dengan pertanyaan "topik apa yang penting dipelajari siswa". Tujuan belajar apa yang ingin diketahui guru mengenai siswa atau apa yang mampu siswa lakukan. Bagaimana guru membantu siswa. Bagaimana guru tahu siswa mencapai tujuan.

Penilaian untuk belajar (Assessment for Learning). Pada penilaian ini guru menggunakan penilaian sebagai alat penyelidikan untuk mengetahui seberapa banyak siswa yang mengetahui dan dapat mengerjakan, dan apa yang membingungkan, konsepsi awal atau kesenjangan yang mungkin terjadi. Keanekaragaman informasi yang luas yang dikoleksi guru mengenai proses belajar siswa memberikan dasar penentuan apa yang mereka perlukan untuk dikerjakan berikutnya untuk bergerak ke arah belajar siswa ke depan. Sebagai dasar untuk menyediakan umpan balik deskriptif bagi siswa dan memutuskan pada kelompok, strategi instruksional dan sumber. (Rethinking Classroom Assessment with Purpose in Mind, h. 29). Istilah formative assessment diinterprestasikan sebagai segala sesuatu yang mencakup aktivitas yang diusahakan oleh guru, dan/atau oleh siswa, yang dilengkapi dengan informasi yang digunakan sebagai umpan balik untuk memodifikasi aktifitas belajar dan mengajar di mana mereka terlibat (Black \& Wlliam, 1998). Evaluasi formatif didefinisikan sebagai evaluasi dari assessmen berdasarkan fakta yang dimaksudkan menyediakan umpan balik dan informasi kepada guru, siswa dan pemangku pendidikan mengenai proses mengajar dan belajar. (Dunn, K.E \& Mulvenon, S.W, 2009) Praktik di dalam kelas adalah formatif yang dibuktikan dengan prestasi siswa yang diperoleh, diinterprestaikan, dan digunakan oleh guru untuk membuat keputusan pada proses belajar mengajar selanjutnya yang lebih baik. (Black \& William, 2009: 7).

Untuk mengetahui tingkatan pengetahuan peserta tes pada materi pelajaran digunakan salah satunya adalah tes pilihan ganda. Tes pilihan ganda 
teridiri dari stem dan opsi yang terdiri dari satu jawaban yang benar dan yang lainnya adalah pengecoh. Tes pilihan ganda yang biasa digunakan adalah tes di mana siswa memilih satu opsi sebagai jawaban yang tepat. Tes pilihan ganda disukai baik oleh organisasi pembuat tes dan guru karena menyediakan sampling konten yang luas, reliabilitas yang tinggi, mudah disekor dan diadministrasikan, kegunaan dalam menguji barbagai konten, dan penyekorannya objektif. Format ini juga mengukur kepandaian dalam banyak sasaran dari level pengetahuan yang bersifat hafalan sampai level yang paling rumit. Sekor tes pilihan ganda dianggap terlalu "tinggi" jika dibandingkan dengan jawaban singkat dan mengisi titik-titik. Tes Pilihan ganda juga dikritik karena peserta tes dapat menjawab dengan menerka. (Frary, 1988: 33). Tes pilihan ganda sebanding dengan constructed response (CR) jika tes pilihan ganda disekor dengan number right score (NRS) karena CR test tidak memberi penalti pada jawaban yang salah dan memberi hadiah pada jawaban partial yang benar (partially correct answer) (Kastener, M \& Stangl, B, 20 I0). Menurut Gronlund (2000), Haladyna (1997, 1999) tes pilihan ganda dianggap beberapa pendidik sebagai tes yang paling bermanfaat dan fleksibel di antara semua bentuk ujian (Slavin, Robert, 20II: 280). Tes Pilihan Ganda banyak dipakai sebagai metoda penilaian selama bertahun-tahun karena menilai beragam kepandaian, cakupan luas pada tujuan, reliabilitas yang tinggi, serta mudah disekor (Yung-Chin et al, 20I0: 163). Tes pilihan ganda dikritik karena membiarkan terjadinya terkaan dan gagal menghargai pengetahuan partial (Buduscu \& Bar-Hillel, 1993).

Tes pilihan ganda dapat disekor dengan berbagai cara. Tes pilihan ganda dapat disekor menggunakan cara yang konvensional, yaitu: dengan metoda penyekoran number right score (NRS). Pada NRS jawaban benar mendapat nilai I jawaban salah dan tidak menjawab diberi nilai 0 . Sekor pada NRS hanya menghitung jumlah yang benar, contoh: $S I=n(R)$ Aturan ini digunakan oleh American College Testing (ACT) dan Graduate Record Examinations (GRE) (Budescue: 1993). NRS mudah digunakan tetapi ia memiliki kelemahan di antaranya berkurangnya validitas karena terkaan dan gagal mengakui adanya partial knowledge (Kurz, Terri Barber, 1999). Pemeriksa tes mendefinisikan miss information pada tes pilihan ganda sebagai pilihan tunggal yang benar yang tidak dipilih, karena peserta tes mempercayai satu pilhan yang salah sebagai jawaban yang benar (Frary, 1980: 79) Informasi yang sebagian (partial informasi) pada tes pilihan ganda didefinisikan sebagai kemampuan untuk menyisihkan beberapa, tetapi tidak seluruhnya pilihan yang salah, jadi membatasi terkaan pada opsi yang sebenarnya yang termasuk di dalamnya pilihan yang benar. (Frary, 1980: 80) Menurut Rogers, secara umum ada dua bentuk terkaan; "terkaan buta" dan "terkaan informasi”. Menerka dengan buta terjadi ketika peserta tes tidak ada gagasan dari jawaban yang benar dan menjawab secara random sementara terkaan informasi terjadi ketika peserta tes menjawab pada item berdasarkan pada pengetahuan parsialnya. Menurut Wright bahwa menebak dapat meningkatkan kesempatan pada individu yang tidak berkualitas, yang dipertimbangkan sebagai respon konstruk yang tidak relevan, perlu dievaluasi kembali orang yang tidak cocok yang disebabkan terkaan setelah diidentifikasi menggunakan estimasi kesalahan (Song Gao 201 I: I). Psychometricians mengembangkan berbagai algorithms penyekoran untuk menjawab hal tersebut. (Kurz, Terri Barber, 1999). Pembuat tes dianjurkan untuk mengadopsi correction for guessing formula (corrected score $=\mathrm{CS}$ ) $\mathrm{Hal}$ ini akan membantu untuk takut menebak. (William J. Umbolon, 2012: 19). Hal yang mendasari gagasan metoda penyekoran ini menurut Betts, Elder, Hartley, \& Trueman (2009) adalah siswa tahu bahwa mereka akan kehilangan angka untuk jawaban yang salah dan ini mengurangi kemungkinan siswa menerka. Rumus $N R S=R$ dan $C S=R-\frac{W}{n-1}$ di mana, $\mathrm{R}=$ jumlah item yang dijawab benar, $W=$ jumlah item yang dijawab salah, dan $\mathrm{n}=$ jumlah pilihan pada setiap item. Besarnya penalti tergantung pada banyaknya opsi, bila opsi ada 5 maka penalti - 1/4, bila opsi ada 4 maka penalti - I/3. (Nitko, Anthony J, 200I: 3 I8). Keunggulan corrected score terhadap number right score sebagai estimasi sekor sesungguhnya tergantung pada kemampuan peserta tes untuk 
mengenal situasi di mana mereka dapat mengeliminasi satu atau lebih alternatif sebagai pilihan yang tidak benar dan mengabaikan item di mana mereka hanya menerka secara random (Bliss, 198I). Tes pilihan ganda yang disekor dengan corrected score cocok dengan sekor pada tes jawaban singkat dan menunjukkan peningkatan pada validasi. Corrected score lebih tinggi daripada number right score (Prihoda et al, 2006)

Pada tahap operasi formal dalam tahapan Piaget siswa berpikir lebih seperti ilmuan. Pemikiran deduktif - hipotetis Piaget (hypothetical-deductive reasoning) merupakan konsep bahwa remaja dapat mengembangkan hipotesis hipotesis (dugaan terbaik) mengenai berbagai cara untuk menyelesaikan masalah dan mencapai sebuah kesimpulan yang sistematis (John W. Santrock, 2009: 58). Siswa SMK seharusnya ada pada tahap operasi formal. Tetapi sayangnya sebagian siswa masih ada pada taraf operasional konkrit selama masa sekolahnya bahkan seumur hidup. Menurut Siegler (1998, 2000) Guru dapat membantu siswa mengembangkan kapasitas berpikir formalnya dengan menempatkan siswa dalam situasi-situasi yang menantang pikiran dan menemukan kelemahan logikanya (Woolfolk, 2009). Teori sosiokultural dari Vygotsky menjelaskan bagaimana proses-proses sosial membentuk belajar dan berpikir. Asumsi Vygotsky setiap perkembangan anak muncul dua kali; pertama di tingkat sosial kemudian ditingkat individual. (Woolfolk, 2008: 69). Mengenai Zona proximal, Vygotsky menekankan bahwa pengetahuan dan pemahaman anak ditopang banyak oleh komunikasi dengan orang lain di lingkungannya. (Winkel, W.S, 2009: 2I). Pada dasarnya ciri belajar adalah terciptanya zona proximal perkembangan, yaitu: membangkitkan belajar, suatu variasi proses perkembangan internal yang dapat bekerja hanya ketika anak berinteraksi dengan yang lainnya dalam lingkungannya dan ketika bekerjasama dengan pasangannya. Sekali proses ini terinternalisasi, mereka menjadi bagian dari perkembangan prestasi independen anak (Vygotsky, 1978). Slavin, Hurley dan Chamberlin (2003) menyatakan bahwa teori Vygotsky mendukung penggunaan strategi pembelajaran kooperatif yang di situ anak bekerja sama untuk membantu belajar satu-sama-lain. (Robert $E$. Slavin, 2009: 60)

Teori kooperatif dan kompetisi awalnya dikembangkan oleh Morton Deutsch (1949) dan kemudian diulas panjang lebar oleh Johnson and Johnson yang mengidentifikasikan 2 dasar tujuan, yaitu: teori interdependence sosial positif dan negatif yang menjelaskan bagaimana individu berinteraksi satu sama lain. Interdependensi positif akan mempromosikan interaksi, pada keadaan ini tidak terjadi konflik sementara interdependensi negatif akan menghambat interaksi sehingga akan terjadi konflik (Deutsch, 20II)

Strategi Pembelajaran Kooperatif (Cooperative learning strategy) memfasilitasi siswa untuk belajar dalam kelompok. Pembelajaran kooperatif merujuk kepada metoda instruksi umum di mana siswa yang berasal dari berbagai tampilan bekerja bersama sebagai sebuah tim untuk menyelesaikan masalah, menyelesaikan tugas, atau menyempurnakan tujuan bersama. Empat prinsip dari pembelajaran kooperatif adalah saling ketergantungan yang positif, masingmasing individu bertanggung jawab, partisipasi yang setara, dan interaksi yang simultan. Kurt Lewin memperhalus gagasan Kofka tahun 1920 an dan tahun 1930 an, untuk adanya kesalingtergantungan harus ada lebih dari satu orang atau entitas yang terlibat dan orang atau entitas harus memiliki dampak pada satu dan yang lainnya sehingga perubahan dalam keadaan satu menyebabkan perubahan keadaan yang lainnya (David W. Johnson dan Roger T Johnson dan Karl Smith, 2013: 4). Slavin, in press; Webb \& Palincsar (1996), sekitar tahun 1970 an riset pada Johns Hopkins University dan di manapun telah didirikan bahwa pembelajaran kooperatif meningkatkan prestasi siswa jika dua unsur kunci digabungkan: tujuan kelompok dan akuntabilitas individual, Jadi kelompok dihargai berdasarkan pada pembelajaran individual dari semua anggota kelompok bukan hanya pada hasil kelompok semata. (Robert Slavin,2008:I52 http://www.revues. org). Strategi Pembelajaran Kooperatif sangat bertolak belakang dengan kompetitif di mana siswa bersaing satu-sama-lain 
untuk mencapai tujuan akademik, hanya satu atau sedikit siswa yang dapat mencapainya dan individualistik di mana siswa bekerja sendiri untuk menyelesaikan tujuan akademiknya yang tidak ada hubungannya dengan apa yang dilakukan oleh siswa yang lain. (Johnson D.W., Johnson R. T and Smith, K. A, 20I3: 3). Johnson \& $R$ Johnson (I99I) menyatakan, penelitian menunjukkan banyak siswa di United States memandang sekolah sebagai usaha kompetisi di mana seorang siswa bekerja lebih baik daripada siswa yang lain. Kompetisi ini diduga telah menyebar ketika siswa masuk sekolah dan tumbuh kuat saat mereka berkembang melalui sekolah (Johnson R.T and David W, 2009) Johnson and Johnson (1989) menyatakan bahwa pada pengajaran tradisional banyak terjadi kompetisi yang merupakan kesaling tergantungan yang negatif. Siswa merasa mereka dapat mencapai tujuan jika dan hanya jika siswa lainnya di kelas gagal untuk mencapai tujuannya. Hasilnya adalah mereka bekerja keras untuk melakukan hal terbaik daripada teman sekelasnya atau mereka tidak peduli karena mereka tidak percaya akan mendapat kesempatan untuk menang (Sani, U T, 20I5: 30). Riyan dan Deci (2000) menyatakan pembelajaran kooperatif dapat membantu memenuhi kebutuhan dasar siswa seperti kebutuhan untuk tampak pintar dan kompeten serta kebutuhan untuk merasa terhubung dengan orang lain di dalam lingkungan sosial. (Eggen dan Kauchak, 2012: 170). Branlett (1994), Megnin (1995), dan Webb, Trapper, Fall, dan Lampe (1995) menekankan keuntungan lainnya dari strategi pengajaran dan pembelajaran kooperatif bahwa siswa yang menolak untuk berbicara dengan bebas pada setting metoda mengajar tradisional menjadi aktif terlibat dalam proses belajar melalui interaksi kelompok. (Juweto 2015: 33). Pembelajaran kooperatif membantu perkembangan prestasi akademik yang lebih tinggi. Pembelajaran kooperatif adalah prediktor yang kuat pada tampilan akademik siswa. Ditemukan hubungan positif yang signifikan antara tingkat nilai penting bagi siswa dan partisipasi aktifnya pada pembelajaran kooperatif. (Tsay, Mina \& Brady, Miranda, 20l0). Metoda pembelajaran kooperatif biasanya tidak mahal dan mudah diterapkan. Guru butuh training yang minimal untuk menggunakan teknik ini. Tambahan pula keefektifannya ia praktis dan menarik bagi guru. Di antaranya STAD, Jigsaw, TGT, dan TAI (Slavin, 1987).

Model Pembelajaran kooperatif yang diteliti pada penelitian ini adalah jigsaw dan STAD. Slavin (1995) menyatakan bahwa STAD merupakan model pembelajaran yang bagus dan sederhana dan tidak sulit sebagai metoda awal untuk guru yang baru menggunakan belajar kooperatif (Slavin, R 1980; Kirik, Ozegan Tastan 2012: 223). Model pembelajaran STAD adalah seperti menerapkan pengajaran kelas utuh yang berfokus pada konsep dan keterampilan. Guru mereview, memperkenalkan pelajaran, menjelaskan dan mencontohkan materi, dan meminta siswa berlatih sambil guru berhati-hati memonitor upaya mereka. Kemudian studi tim menggantikan latihan mandiri. Asessmen diberikan sebagai dasar bagi nilai perbaikan dan penghargaan tim (Eggen, 20I2: 147). Menggunakan tujuan kelompok atau memberi hadiah pada kelompok meningkatkan hasil prestasi belajar kooperatif jika dan hanya jika hadiah pada kelompok berdasarkan pada belajar individu dari semua anggota kelompok (Slavin, 1995). Pada STAD guru harus memonitor perkembangan kelompok dan memberi hadiah kepada kelompok yang satu atau lebih anggotanya yang memperlihatkan peningkatan. Hal yang melatar-belakangi STAD adalah untuk memotivasi siswa mendorong dan saling membantu untuk menguasai skill yang dipresentasikan oleh guru, jika mereka ingin tim mereka memperoleh hadiah, mereka harus membantu teman satu tim belajar materi. (Slavin, 1987) Menurut Hertz-Lazarowithz \& Miller, kebanyakan guru memandang STAD sebagai metoda pengajaran yang mudah diaplikasikan, dekat dan konsisten dengan filosofi mengajar dan praktik. (Yeung, 20I5: 3I)

Pada teknik "subjek Jigsaw" yang dikembangkan oleh Daymus, siswa merupakan anggota dari dua kelompok yang berbeda, "home group" dan "Jigsaw group." Pada awalnya siswa bertemu di home group dan setiap anggota home group ditugasi satu porsi materi untuk dipelajari seperti "seorang pakar." Di kelas siswa pada home group mengajarkan satu-sama-lain informasi yang telah ia pelajari. Materi yang telah dipelajari 
dan didiskusikan kemudian dipresentasikan di depan kelas. Kemahiran siswa dalam mempresentasikan materi harus mendapatkan perhatian yang lebih. Kemudian home group berpencar seperti kepingan puzzle dan siswa bergerak ke kelompok Jigsaw yang terdiri dari anggota kelompok home group lainnya yang telah ditugasi subtopik yang berbeda. Di kelompok Jigsaw siswa berdiskusi materi untuk menjamin mereka mengerti kemudian siswa kembali ke home group, di mana mereka mengajarkan materi kepada satu sama lain dalam anggota kelompoknya. (Doymus, 2007: 25I). Siswa yang memberi penjelasan bagaimana menyelesaikan tugas memperlihatkan prestasi yang lebih tinggi daripada siswa yang tidak aktif terlibat dalam interaksi kelompok bahkan pada tingkat kemampuan yang dibuat konstan (Webb, 1982). Siswa yang berkemampuan rendah diuntungkan pada kerja di dalam kelompok dengan siswa berkemampuan sedang atau di atas rata-rata. (Webb, Nemer; Chizhik, Alex dan Sugrue, Brenda, 1997).

Meskipun pembelajaran kooperatif dapat secara potensial menawarkan kesempatan belajar yang berharga, namun guru harus hati-hati mengadopsinya. Menempatkan siswa dalam kelompok dan menyuruh mereka bekerja sama tidaklah menciptakan kerjasama yang efektif. (Johnson \& F johnson, 2009; Johnson D.W \& Johnson, R.T, 20I3). Komentar secara tertulis mengungkapkan sikap yang berbeda terhadap pembelajaran kooperatif. Sebagian siswa menilai mendapat kesempatan berdiskusi sementara yang lain frustasi karena berkurangnya waktu bagi tutor untuk mengajar, mencatat, dan menjawab dengan jawaban yang benar. Jika belajar kooperatif membuat siswa masuk akal mereka harus tahu bagaimana diskusi mereka dengan pasangannya memberikan perbedaan terhadap keberhasilan belajar mereka, jadi aktifitas pembelajaran kooperatif perlu diikuti dengan kriteria ujian dan penilaian. (Hermann, KJ, 20I3). Hambatan terhadap belajar kooperatif dapat dihindarkan jika distrukturkan dengan sesuai. Kefektifan belajar kooperatif tergantung pada lima unsur dasar yang terstruktur, yaitu: positif interdependence, akuntabilitas individual dan kelompok, interaksi promotif, mengajar siswa syarat interpersonal, dan kemahiran kelompok kecil dan proses kelompok. (Johnson, D.W., \& Johnson, R.T, 20I3)

\section{Tujuan Penelitian}

Penelitian ini bertujuan untuk menjawab permasalahan antara strategi pembelajaran kooperatif dan jenis penyekoran pada tes formatif pilihan ganda terhadap hasil belajar kimia siswa. Pertanyaan tersebut terdiri dari: (I) Apakah terdapat perbedaan hasil belajar kimia siswa pada kelompok pembelajaran kooperatif model Jigsaw dan hasil belajar kimia siswa pada kelompok pembelajaran kooperatif model STAD? dan (2) Apakah terdapat perbedaan hasil belajar kimia siswa pada kelompok yang tes formatif pilihan gandanya disekor dengan corrected score (CS) dan hasil belajar kimia siswa pada kelompok yang tes formatif pilihan gandanya disekor dengan number right score (NRS)?

\section{Metode Penelitian}

Penelitian ini menggunakan factorial design 2 $x$ 2. Variabel penelitian terdiri dari: (I) variabel terikat, yaitu: hasil belajar kimia dan (2) variabel bebas, yaitu: variabel $A$ perlakuan strategi pembelajaran kooperatif $\left(A_{1}\right.$ : model Jigsaw dan $A_{2}$ : model STAD) dan variabel $B$ jenis penyekoran ( $B_{1}$ : corrected score dan $B_{2}$ number right score).

Populasi target dalam penelitian ini adalah siswa SMK kelas I,2,3, dan 4 (yang aktif dalam pembelajaran kimia adalah kelas I,2, dan 3, sedangkan kelas 4 ada di Industri). Total populasi 923 siswa. Populasi terjangkau adalah siswa yang mengambil mata pelajaran kimia di kelas XI pada 5 jurusan yang masing-masing terdiri dari dua jurusan sehingga total adalah 10 kelas. Penentuan kelas eksperimen dilakukan dengan mengambil dua jurusan di antara 5 jurusan yang memiliki ciri yang sama, yaitu: Teknik Permesinan dan Teknik Kendaraan Ringan yang masing-masing jurusan diambil dua kelas sehingga ada 4 kelas yang digunakan dalam penelitian ini, dua kelas teknik permesinan (TP) dan dua kelas teknik kendaraan ringan (TKR). Keempat kelas ini dirandom, dari 
dua kelas tiap jurusan ini diacak untuk diberi perlakuan pembelajaran kooperatif model Jigsaw dan STAD dan untuk menentukan jenis penyekoran. Hasil yang diperoleh adalah kelompok pembelajaran kooperatif model Jigsaw yang tes formatifnya disekor dengan corrected score, yaitu: kelas Teknik Kendaraan Ringan 2 dengan jumlah siswa 29, kelompok pembelajaran kooperatif model STAD yang tes formatifnya disekor dengan corrected score, yaitu: kelas Teknik Permesinan 2 dengan jumlah siswa 32, kelompok pembelajaran kooperatif model STAD yang tes formatifnya disekor dengan number right score, yaitu: kelas Teknik Kendaraan Ringan I dengan jumlah siswa 3I, dan kelompok pembelajaran kooperatif model Jigsaw yang tes formatifnya disekor dengan number right score, yaitu: kelas Teknik Permesinan I dengan jumlah siswa 31. Selama 6 minggu siswa diberi materi dengan topik laju reaksi yang dipecah menjadi 6 bagian. Setiap akhir satu sesi diberi 10 item tes formatif berbentuk tes pilihan ganda dengan 5 pilihan jawaban. Pada penelitian ini tiap kelompok diundi untuk dijadikan sampel sebanyak I 3 siswa (tiap sel terdiri dari 13 siswa) sehingga jumlah sampel seluruhnya adalah 52 siswa. Penelitian ini menggunakan seorang guru kimia yang sudah lama mengajar. Instrumen pada penelitian ini adalah tes laju reaksi (TLR) yang terdiri dari 40 butir pertanyaan pilihan ganda dengan 5 pilihan jawaban. Tes laju reaksi dikembangkan oleh peneliti. Tes ini diujicobakan pada 359 siswa sebelumnya yang tidak terlibat pada peneltian ini tetapi telah mempelajari laju reaksi. Dengan menggunakan Anates diperoleh reliabilitas 0,70 dan telah divalidasi oleh 5 pakar kimia, setelah dihitung menggunakan CVR semua butir dapat dipertahankan atau valid. 6 tes laju reaksi lainnya digunakan sebagai perlakuan selama enam kali pertemuan. Tes tersebut terdiri dari 10 item tes laju reaksi yang dikembangkan oleh penulis.

\section{HASIL PENELITIAN}

Berdasarkan data hasil belajar kimia yang diperoleh melalui 40 butir tes soal pilihan ganda diketahui sekor terendah 50 dan tertinggi adalah 70. Sebaran data dideskripsikan dalam Tabel I.
Tabel I. Deskripsi sebaran data

\begin{tabular}{|l|l|l|l|l|l|l|l|l|}
\hline \multirow{2}{*}{$\begin{array}{l}\text { sebaran } \\
\text { data }\end{array}$} & \multicolumn{7}{|c|}{ Kelompok perlakuan } \\
\cline { 2 - 9 } mean & $A_{1}$ & $A_{2}$ & $B_{1}$ & $B_{2}$ & $A_{1} B_{1}$ & $A_{1} B_{2}$ & $A_{2} B_{1}$ & $A_{2} B_{2}$ \\
\hline $\begin{array}{l}\text { stand. } \\
\text { dev }\end{array}$ & 60,7 & 62,2 & 62,7 & 60,2 & 64,4 & 57,1 & 61,2 & 63,3 \\
\hline $\min$ & 50 & 5,3 & 4,08 & 5,3 & 3,97 & 4,06 & 3,625 & 4,71 \\
\hline $\max$ & 70 & 70 & 70 & 70 & 70 & 62,5 & 67,5 & 70 \\
\hline
\end{tabular}

Berdasarkan perhitungan hipotesis, menunjukkan adanya interaksi antara pendekatan pembelajaran dan jenis penyekoran maka dilakukan uji lanjut dengan menggunakan uji-t Dunnet. Hasil penghitungan uji-t Dunnet disajikan pada Tabel 2.

Tabel 2. Uji-t Dunnet

\begin{tabular}{|l|l|l|l|}
\hline Pengujian & $\mathrm{t}_{\text {hitung }}$ & $\mathrm{t}_{\text {tabel }}$ & Keputusan \\
\hline $\mathrm{t}_{\text {(AIBI)(A2BI) }}$ & 2,204 & $\mathrm{I}, 68$ & $\mathrm{H}_{0}$ ditolak \\
\hline $\mathrm{t}_{\text {(AIB2)(A2B2) }}$ & $3,8 \mathrm{IO}$ & $\mathrm{I}, 68$ & $\mathrm{H}_{0}$ ditolak \\
\hline $\mathrm{t}_{\text {(AIBI)(AIB2) }}$ & 4,529 & $\mathrm{I}, 68$ & $\mathrm{H}_{0}$ ditolak \\
\hline $\mathrm{t}_{\text {(A2BI)(A2B2) }}$ & $\mathrm{I}, 304$ & $\mathrm{I}, 68$ & $\mathrm{H}_{0}$ diterima \\
\hline
\end{tabular}

\section{Perbedaan hasil belajar kimia siswa pada kelompok yang menggunakan pembelajaran kooperatif model Jigsaw dan model STAD (main effect A)}

Hasil analisa dengan menggunakan ANAVA dua jalan, $F_{0}(A)=1,598<F_{\text {tabel }}=4,04$ pada taraf signifikan $\propto=0,05$ dengan $\mathrm{db}$ pembilang $\mathrm{db}(\mathrm{A})=$ I dan $d b$ penyebut $d b(D)=48$, maka $H_{0}$ diterima, Jadi tidak terdapat perbedaan rata-rata hasil belajar kimia antara kelompok siswa yang diberi pembelajaran kooperatif model Jigsaw dan kelompok siswa yang diberi pembelajaran kooperatif model STAD.

Perbedaan hasil belajar kimia siswa pada kelompok yang tes formatifnya disekor dengan corrected score dan kelompok yang tes formatifnya disekor dengan number right score (main effect B) 
Hasil analisa dengan menggunakan ANAVA dua jalan dengan hipotesa pada taraf signifikan $\alpha=$ 0,05 dengan nilai $F$ hitung $=5,176$ lebih besar dari $t_{\text {tabel }}=4,04$ maka $\mathrm{H}_{0}$ ditolak, artinya terdapat perbedaan hasil belajar kimia antara siswa yang tes formatif pilihan gandanya disekor dengan CS dan NRS. Uji satu pihak yang dihitung dengan rumus; $t_{0}(B)=\sqrt{5,176}=2,27>t_{(0,05,48)}$ $=\mathrm{I}, 68$ atau $\mathrm{H}_{0}$ ditolak, dengan demikian hasil belajar kimia siswa yang tes formatif pilihan gandanya disekor dengan corrected score lebih tinggi daripada siswa yang tes formatif pilihan gandanya disekor dengan number right score.

Interaksi antara model pembelajaran kooperatif dengan jenis penyekoran terhadap hasil belajar kimia (pengaruh Interaksi AB)

Hasil analisis data dengan menggunakan ANAVA dua jalan pada taraf signifkansi $\alpha=0,05$, tersebut di atas, memberikan nilai $F_{\text {Hitung }}=17,045$ lebih besar dari $\mathrm{F}_{\text {tabel }}=4,04$ maka $\mathrm{H}_{0}$ ditolak, dengan demikian terdapat pengaruh interaksi antara model pembelajaran kooperatif dan jenis penyekoran tes formatif pilihan ganda. Adapun bentuk interaksi antara model pembelajaran kooperatif dan jenis penyekoran dapat dilihat pada Gambar I. Berikut ini:

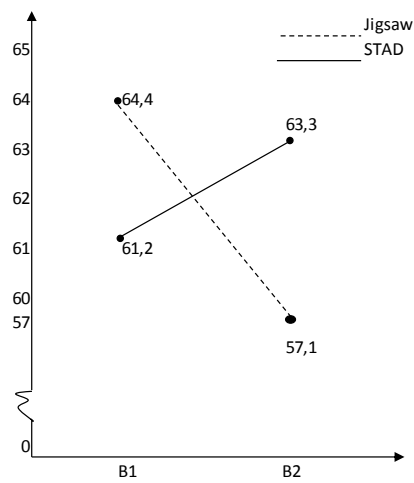

$$
\begin{aligned}
& \mathrm{B}_{1}=\text { corrected } \\
& \text { score (CS) } \\
& \mathrm{B}_{2}=\text { number right } \\
& \text { score (NRS) }
\end{aligned}
$$

Gambar I. Grafik interaksi antara Model Pembelajaran Kooperatif dengan jenis penyekoran Tes Formatif Pilihan Ganda.

Pembelajaran kooperatif model Jigsaw $\left(A_{1}\right)$ dan STAD $\left(A_{2}\right)$ khusus kelompok siswa yang tes formatif pilihan gandanya disekor dengan corrected score $\left(B_{1}\right)$, yaitu: kelompok $A_{1} B_{\text {I }}$ dan $A_{2} B_{\text {I }}$

Hasil Uji lanjut dengan uji-t Dunnet pada Tabel 2 diperoleh nilai $\mathrm{t}_{\text {hitung }}=2,204>\mathrm{t}_{\text {tabel }}=1,68$ pada $\alpha=0,05 \mathrm{H}_{0}$ ditolak. Dengan demikian dapat disimpulkan bahwa khusus pada kelompok siswa yang tes formatif pilihan gandanya disekor dengan corrected score, hasil belajar kimia kelompok siswa yang menggunakan pembelajaran kooperatif model Jigsaw lebih tinggi daripada hasil belajar kimia kelompok siswa yang menggunakan pembelajaran kooperatif model STAD.

Pembelajaran kooperatif model Jigsaw dan STAD khusus kelompok siswa yang tes formatif pilihan gandanya disekor dengan number right score, yaitu: kelompok $A_{1} B_{2}$ dan $\mathbf{A}_{\mathbf{2}} \mathbf{B}_{2}$

Hasil analisa data dengan menggunakan uji tDunnet kelompok siswa yang menggunakan pembelajaran kooperatif model Jigsaw yang tes formatif pilihan gandanya disekor dengan number right score pada taraf signifikansi $\alpha=0,05$ tersebut di atas, memberikan nilai $t_{0}=3,810>t_{\text {tab }}=1,68$, maka $\mathrm{H}_{0}$ ditolak. Dengan demikian dapat disimpulkan bahwa pada kelompok siswa yang tes formatif pilihan gandanya disekor dengan number right score, hasil belajar kimia kelompok siswa yang menggunakan pembelajaran kooperatif model Jigsaw lebih rendah daripada hasil belajar kimia kelompok siswa yang menggunakan pembelajaran kooperatif model STAD.

Penyekoran tes formatif pilihan ganda yang disekor dengan corrected score dan number right score khusus untuk kelompok siswa yang menggunakan pembelajaran kooperatif model Jigsaw $\left(A_{1} B_{1}\right.$ dan $\left.A_{1} B_{2}\right)$

Hasil analisa data dengan menggunakan uji tDunnet siswa yang menggunakan penyekoran corrected score dan number right score pada taraf signifikan $\alpha=0,05$, tersebut di atas, memberikan nilai $t_{o}=4,529$ lebih besar dari $t_{\text {tab }}=1,68$ maka $\mathrm{H}_{0}$ ditolak. Dengan demikian dapat disimpulkan bahwa pada kelompok siswa yang menggunakan 
pembelajaran kooperatif model Jigsaw, hasil belajar kimia kelompok siswa yang tes formatif pilihan gandanya disekor dengan corrected score lebih tinggi daripada yang disekor dengan number right score.

\section{Penyekoran corrected score dan number right score khusus untuk kelompok siswa yang menggunakan pembelajaran kooperatif model STAD $\left(A_{2} B_{1}\right.$ dan $\left.A_{2} B_{2}\right)$}

Hasil analisa data dengan menggunakan uji tDunnet siswa yang disekor dengan corrected score dan number right score yang menggunakan pembelajaran kooperatif model STAD pada taraf signifikansi $\alpha=0,05$, tersebut di atas, memberikan nilai $t_{0}=1,304$ lebih kecil dari $t_{\text {tab }}=1,68$ maka $\mathrm{H}_{0}$ diterima. Dengan demikian dapat disimpulkan bahwa pada kelompok siswa hasil belajar kimia yang menggunakan pembelajaran kooperatif model STAD yang disekor dengan corrected score lebih rendah daripada hasil belajar siswa yang disekor dengan number right score.

\section{Pembahasan Penelitian}

Hasil pengujian hipotesis pertama menunjukkan bahwa hasil belajar kimia kelompok siswa yang diberi pembelajaran kooperatif model Jigsaw tidak berbeda dengan hasil belajar kimia kelompok siswa yang diberi pembelajaran kooperatif model STAD, namun rata-rata perolehan pada STAD lebih tinggi daripada Jigsaw. Kemungkinan pada Jigsaw karena mereka harus mencari materi dan mengkajinya sehingga mengurangi waktu mereka untuk mempelajari materi yang akan dipresentasikan meskipun mereka dibantu oleh guru dan mereka juga kehilangan kesempatan untuk mempelajari materi yang dipresentasikan oleh teman sekelasnya.

Pembuktian hipotesis berdasarkan kajian empiris yang dilakukan peneliti didukung oleh teori dan konsep yang dikemukakan oleh pakar seperti Slavin, STAD merupakan metoda belajar tim siswa yang paling sederhana, tidak sulit digunakan. Tim pada STAD terdiri dari tampilan siswa yang tinggi, rata-rata, dan rendah. Pada Jigsaw materi akademik dibagi dalam beberapa seksi. Tiap tim merupakan pakar pada seksinya dan menginstruksikan kepada anggota timnya. Hasil penelitian membuktikan bahwa keduanya efektif pada capaian akademik dan berguna dalam mengintegrasikan biracial dan mainstreamed classrooms (Slavin, 1980). Pada penelitian lainnya menunjukkan bahwa siswa lebih mengapresiasikan STAD daripada pengajaran tradisional, demikian pula dengan Jigsaw yang lebih diapresiasikan daripada pengajaran tradisional. Siswa memperlihatkan apresiasi yang sama antara Jigsaw dan STAD. Siswa mendapat sekor yang tinggi pada tes prestasi yang dilaksanan pada kedua kondisi pembelajaran kooperatif Jigsaw dan STAD namun pada STAD rata-rata sekor perolehannya lebih tinggi daripada Jigsaw. (Alabekee, Egbulefu Christian et al, 20I5). Guru kimia United Arab Emirat merasa nyaman ketika STAD diaplikasikan dengan baik pada kurikulum yang sama dengan siswa yang serupa (Balfakih, 2010: 622). Keefektifan siswa dalam model STAD (56), Jigsaw (46), dan TGT (40). Hasil pembelajaran siswa dalam model STAD $(80,33)$, Jigsaw $(80,23)$, dan TGT $(80,03)$. Kemudian berdasarkan uji lanjut anava (uji scheffe) disimpulkan bahwa model kooperatif tipe STAD paling effektif kemudian TGT dan Jigsaw dalam meningkatkan keaktifan hasil belajar geografi. (Noorhadi dan Muhsinatun Siasah Masruri, 20I4). STAD teknik lebih efektif daripada Jigsaw terhadap reading comprehensive siswa dalam pelajaran bahasa Inggris pada motivasi yang berbeda. (Eko Mulyono, 20/3). STAD dan Jigsaw keduanya memfasilitasi mata pelajaran Biologi di tingkat sekolah menengah namun STAD lebih memfasilitasi belajar daripada Jigsaw (STAD lebih unggul dari Jigsaw). (Achor, Emmanuel E \& Wude, Musa Habu, 2014). Slavin (1995) menemukan bahwa riset pada Jigsaw yang original secara umum tidak ditemukan efek positif pada prestasi siswa. Salah satu masalah dengan metoda ini siswa memiliki keterbatasan mengekspose materi daripada yang mereka pelajari, sehingga perolehan belajar pada topiknya sendiri mungkin digantikan oleh kehilangan pada topik kelompok lainnya (Slavin, I995), namun pada kajian Mattingly dan Van Sickle (199I) bentuk Jigsaw yang ditambah pemberian hadiah pada 
model yang original ditemukan hasil prestasi yang positif (Slavin, 1995).

Pengujian hipotesis kedua menunjukkan bahwa hasil belajar kimia kelompok siswa yang tes formatif pilihan gandanya disekor dengan corrected score (CS) lebih tinggi daripada kelompok siswa yang tes formatif pilihan gandanya disekor dengan number right score (NRS). Siswa pada kelompok CS kemungkinan terdiri dari siswa yang penghindar resiko sehingga mereka berhati-hati atau paling tidak partial knowledgenya bekerja sehingga mereka dapat menerka dengan baik.

Pengujian hipotesis ketiga menunjukkan adanya interaksi antara model pembelajaran dan jenis penyekoran. Kefektifan jenis penyekoran tergantung pada model pembelajaran kooperatif. Penyekoran tes formatif pilhan ganda dengan number right score lebih cocok bagi kelompok siswa yang diberi pembelajaran kooperatif model STAD, sementara bagi kelompok siswa yang diberi pembelajaran kooperatif model Jigsaw mereka lebih cocok bila tes formatif pilihan gandanya disekor dengan corrected score. Perencanaan pembelajaran dan pengambilan keputusan oleh seorang guru harus dirancang dengan tepat pada keseluruhan fase pengajaran agar dapat membantu perkembangan pembelajaran siswa. Pembelajaran apa yang digunakan, apa tujuannya, dan bagaimana mengevaluasi perkembangan siswa. Menurut Gagne \& Briggs (1979) salah satu asumsi tentang desain pembelajaran "Perencanaan pembelajaran tidak boleh sembarangan atau sekedar memberikan lingkungan yang mengasuh. Perencanaan yang sembarangan dapat melahirkan orang dewasa yang tidak kompeten karena itu, pembelajaran harus dikembangkan sesistematis mungkin. (Greadler, Margaret E. 20 I I: 196)

Pengujian hipotesis keempat menunjukkan bahwa khusus pada kelompok siswa yang tes formatif pilihan gandanya disekor dengan corrected score, hasil belajar kimia kelompok siswa yang menggunakan pembelajaran kooperatif model Jigsaw lebih tinggi daripada hasil belajar kimia kelompok siswa yang menggunakan pembelajaran kooperatif model STAD. Dengan demikian pembelajaran kooperatif model Jigsaw lebih efektif bila tes formatif pilihan gandanya disekor dengan corrected score (CS). Corrected score melatih siswa untuk tidak menebak pada tes pilihan ganda. Model pengkoreksian benar dikurang salah (CS) adalah unggul dan memberikan penalti pada siswa untuk respon yang salah (Kurz, 1999). Dasar yang melatari gagasan di belakang metoda penyekoran ini menurut Betts, Elder, Hartley, \& Trueman (2009) adalah siswa mengakui mereka akan kehilangan angka untuk jawaban yang salah. (Ellen Lasage 2013: 189), sebagai konsekuensinya siswa tidak berani menebak, dan ini diharapkan meningkatkan reliabilitas dan validitas tes karena sekor tes adalah refleksi yang benar dari kemampuan siswa. $\mathrm{Hal}$ yang menjadi keprihatinan pada CS adalah faktor-faktor external seperti kesudian mengambil resiko dan membuat takut peserta tes yang bijak dalam menerjemahkan sekor yang diperoleh. (Kurz, Terri Barber, 1999: 17). Pada siswa kelompok Jigsaw kemungkinan terdiri dari siswa yang partial knowledgenya bekerja dan mereka berhati-hati.

Pengujian hipotesis yang kelima menunjukkan bahwa khusus kelompok siswa yang tes formatif pilihan gandanya disekor dengan number right score, kelompok siswa yang menggunakan pembelajaran kooperatif model Jigsaw lebih rendah daripada yang menggunakan pembelajaran kooperatif model STAD. Pada number right score hasil tes sangat mudah dipengaruhi oleh terkaan karena peserta tes tidak diberi penalti untuk jawaban yang salah. Perlakuan NRS pada siswa menyebabkan siswa pada kelompok ini berani untuk mengambil resiko daripada kelompok siswa lainnya. Kelompok siswa yang menggunakan pembelajaran kooperatif model Jigsaw adalah kelompok siswa yang terbiasa mengkaji materi untuk dipresentasikan dan mereka biasa menjawab pertanyaan rekannya ketika presentasi sehingga kemungkinan mereka terdiri dari siswa yang enggan untuk menebak. Kalaupun mereka menebak partial knowledgenya tidak bekerja. Sementara kelompok STAD kemungkinan terdiri dari mereka yang memiliki partial knowledge sehingga mereka dapat menjawab menggunakan strategi yang mereka miliki. Seperti yang dinyatakan oleh Hutchinson (I99I) dengan informasi parsial, peserta tes dapat 
mengeliminasi satu dari beberapa pengecoh yang jelas kelihatan salah, dan ia menerka secara random di antara yang sisa (Gao, Song, 20 I I: 4).

Pengujian hipotesis yang keenam menunjukkan bahwa pada kelompok siswa yang menggunakan pembelajaran kooperatif model Jigsaw, hasil belajar kimia kelompok siswa yang tes formatif pilihan gandanya disekor dengan corrected score lebih tinggi daripada yang disekor dengan number right score. Kelompok siswa yang menggunakan kooperatif model Jigsaw adalah siswa-siswi yang dilatih untuk melaksanakan presentasi. Sebelum presentasi mereka harus mengkaji materi yang akan dipresentasikan dengan cermat. Pada saat presentasi mereka harus dapat menjawab pertanyaan yang diajukan oleh teman dengan baik. Pada corrected score, mereka dilatih untuk memilih opsi pada tes pilihan ganda dengan cermat, rasional, dan ingin memaksimalkan korelasi antara sekor dan pengetahuan, sehingga mereka takut untuk menerka dan menghindari resiko dibandingkan dengan rekan mereka yang disekor dengan number right score. Pada number right score mereka diberi kesempatan untuk menebak sehingga mereka dilatih untuk mengambil resiko yang sayangnya ada yang memiliki absen knowledge dan partial knowledgenya tidak berfungsi. Implikasi dari analisis bahwa number-right score tidaklah superior terhadap formula scoring (corrected score) jika peserta tes ingin memaksimalkan korelasi antara sekor dan pengetahuan, dan siswa memiliki rasional dan perilaku yang berhati-hati. (Espinosa \& Gardeazabal 20l0: 21).

Pengujian hipotesis yang ketujuh menunjukkan bahwa hasil belajar kimia pada kelompok siswa yang diberi pembelajaran kooperatif model STAD yang tes formatif pilihan gandanya disekor dengan Corrected Score lebih rendah daripada yang disekor dengan number right score. Kelompok siswa yang menggunakan pembelajaran kooperatif model STAD yang tes formatifnya disekor dengan number right score terdiri dari siswa yang partial knowledgenya bekerja, pengikut tes yang berani mengambil resiko pada terkaan dan siswa yang menerka pada sedikit item. Sementara kelompok siswa yang disekor dengan corrected score terdiri dari siswa- siswi yang terlalu berhati-hati dan takut menerka, penghindar resiko tetapi sayangnya mereka absen knowledge dan tidak memaksimalkan antara sekor dan pengetahuan.

\section{KESIMPULAN DAN SARAN}

Penelitian ini bertujuan untuk menyelidiki pengaruh jenis penyekoran pada model pembelajaran. Temuan dari penelitian ini menyatakan bahwa ada perbedaan antara jenis penyekoran CS dan NRS. Jenis penyekoran tergantung pada model pembelajaran kooperatif. CS lebih efektif daripada NRS pada Jigsaw dan NRS lebih efektif daripada CS pada STAD.

Mengingat keterbatasan penelitian ini, maka penulis menyarankan kepada peneliti lain untuk melakukan penelitian selanjutnya yang melibatkan variabel-variabel lain yang menyertakan pengaruh motivasi dan jenis penyekoran lainnya seperti partial credit scoring, confidence scoring, atau logicalchoice weight dalam membedakan dua jenis model pembelajaran dan pada jenis penyekoran yang melibatkan soal pilihan ganda yang dapat menyelidiki partial knowledge siswa. Hal ini merupakan rekomendasi agar supaya dapat mengukur pemahaman siswa pada pengetahuan yang diperoleh dan bukan pada strategi siswa menjawab yang selama ini diperdebatkan para penulis lainnya.

\section{Daftar Pustaka}

Achor, Emmanuel E and Wude, Musa Habu. (20l4). Looking for more Facilitative Cooperative Learning Strategy For Biology: Students' Team Achievement Division or Jigsaw? British Journal of Education Society \& Behavioural Science 4(12): Pp.1664-1675, Science Domain International. www.Sciencedomain.org.

Ahiakwo, Macson J \& Isiguzo, Chigozirim. (20I5). Students' Conceptions and Misconceptions in Chemical Kinetics in Port Harcourt Metropolis of Nigeria. African Journal of Chemical Education-AJCE 5(2). 
Alabekee, Egbulefu Christian; Samuel Amaele; Osaat, Sunday D (20I5). Effect of Cooperative Learning Strategy on Students Learning Experience and Achievements in Mathematics, International Journal of Education Learning and Development, Vol 3, No 4, pp. 6775. www.eajournals.org.

Anderson, R. D. (1992). Issues of curriculum reform in science, mathematics and higher order thinking across the disciplines. Office of educational Research and Improvement Washington DC. ERIC.

Balfakih, Nagib, M.A. (2010). The effectiveness of student team achievement division (STAD) for teaching high school chemistry in the United Arab Emirates. International Journal of Science Education., 25(5): Pp.605624. http://www.tandfonline.com/loi/tsed20.

BEKTAȘLI, Behzat and ÇAKMAKCl, Gültekin. (20II). Consistency of Students' Idea about the Concept of Rate across Different Contexts, Education and Sience, Vol 36, No 162.

Betts, Lucy R; Alder, Tracey J; Hartley, J \& Trueman, M. (2009). Does correction for Guessing reduce students' performance on multiple choice examinations? Yes? No? Sometimes? Assessment \& Evaluation in Higher education, 34(I) PP. I-I5.

Black, P \& William, D. (2009). Developing the theory of formative assessment, Evaluation and Accountability, 2I(I), PP. 5-3I |0.1007/s | |092-008-9068-5.

Black, Paul \& William, D.(1998) Assessment and Classroom Learning, Assessment in Education, Vol. 5, No. I, 1998 http://www.tandfonline .com/loi/ceie20.

Bliss, Leonard B. (198I). An Empirical Test for a Strategy for Training Examinees in the Use of Partial Information in Taking Multiple Choice Tests. Paper presented at the Annual Meeting of the American Educational Research Association, Los Angeles April I3, 198 I.

Budescu, David and Bar-Hillel, Maya. (1993) To Guess or Not to Guess: A decisionTheoritic View of Formula Scoring. Journal of Educational Measurement Vol. 30 No. 4 pp. 277-29l.

Chairam, Sanoe et al. (2009). Enhancing Thai students' learning of chemical kinetics, Research in science \& Technological Education. http://www.informaworld.com.

Chairam, Sanoe., \& Klahan, Nutsuda. (20I5). Exploring Secondary Students' Understanding of chemical Kinetics through Inquiry Based Learning Activities. Eurasia Journal of Mathematics, Science \& Technology Education, II(5): 937-956 Doi:I0.I2973/ eurasia. 20I5.1365a.

Dejong, Onno. (2003). Chemical Education: Towards Research-based Practice. Section E Developing Teachers and Chemical Education. Kluwer academic Publishers New York, Boston, Dordrecht, London, Moscow. http://kluwer on line.com.

Deutsch, M. (20II). Conflict, Interdependence, and Justice The Intelectual legacy of Morton, XVIII, p. 327. http://www.Springer. com/978-I44I 9-9993-I.

Doyumus, Kemal. (2008). Teaching Chemical Equilibrium with Jigsaw Technique. Res Sci duc 38: pp. 249-260 Springer.

Dunn, Karee E \& Mulvenon, Sean W. (2009). A Critical Review of Research on Formative Assessment: The Limited Scientific Evidence of the Impact of Formative Assessment in Education Practic Assessment, Research \& Evaluation. Volume 14, Number 7.

Eggen, Paul, Kauchak, Don. (20I2). Strategi dan Model Pembelajaran Mengajar Konten dan Keterampilan Berpikir. Jakarta: PT Indeks. 
Espinosa, Maria Paz. Gardeazabal, Javier. (2007-2008). Optimal Correction for Guessing in Multiple Choice Tests. University of the Basque Country, DFAEII WP Series. http://ww.ehu.es/FAEIl.

Frary, Robert B. (1980). The Effect of Misinformation, Partial Information, and Guessing on Expected Multiple-Choice Test item Scores. Virginia Polytechnic and State University. http://purl.umn.edu/93227.

Frary, Robert B. (1988). Formula Scoring of Multiple-Choice Test (Correction For Guessing), Virginia Polytechnic Institute and State University.

Frary, Robert B. (1989). Partial-Credit Scoring Methods for Multiple-Choice Tests. Applied Measurement in Education, 2(I), Pp. 79-96.

G.A, Juweto. (20I5). Effect of Jigsaw Cooperatif Teaching Learning Strategy and Scholl Locations on student Achievement and Attitude Towards Biology in Secondary School in Delta State, International Journal of Education and Research 3: pp. 31- 40.

Gao, Song. (20II). The Exploration of the Relationship Between Guessing and Latent Ability in IRT Models. Dissertations, Department of Education Psychology and Special Education in the Graduate School Southern Ilinois University Carbondale. http://opensiuc.lib.siu.edu/dessertations.

Gilbert, John K; Dejong, Onno; Justi, Rosária, Justi; Treagust, David F; Van Driel, Jan H. (2003). Chemical Education: Towards Research-based Practice. Kluwer academic Publishers New York, Boston, Dordecht, London, Moscow. $\quad$ http://Kluwer online.com.

Gredler, Margaret E. (201 I). Learning and Instruction: Teori dan Aplikasi. Jakarta: Kencana.
Heck, Andre. (20I2). Modelling Chemical Kinetics Graphically, Korteweg-deVries Institute Universiteit Van Amsterdam The Nederland.

Herman, Kim J. (20I3). The Impact of cooperative learning on student engagement: Results from an intervention, Active learning in higher education.

J, Anthony Nitko. (200I). Educational Assessment of Students. New Jersey: Prantice-Hall.

Jegede, S.A. (2007). Students'anxiety towards the learning of chemistry in some Nigerian secondary Schools. AEECCAF357 vol 2(7) pp. 193-197.

Johnson, D. W, Johnson, Roger. T and Smith, K. A. (20I3). Cooperative Learning: Improving University Instruction By Basing Practice On Validated Theory, Journal on Excellence in University Teaching.

Johnson, D. W \& Johnson R.T. (2009). An overview of Cooperative Learning. http://www.cooperation.org/pages/over view paper.html.

Justi, Rosária. (2003). Chemical Education: Towards Research-based Practice. Section D Chapter 13. Teaching and Learning Chemical Kinetics. Kluwer academic Publishers New York, Boston, Dordrecht, London, Moscow. http://kluwer on line.com.

Kadir. (2010). Statistika untuk Penelitian IImuilmu Sosial, Jakarta: Rosemata Sampurna.

Kadir. (2016). Statistika Terapan Konsep, Contoh dan Analisis Data dengan program SPSS/ Lisrel dalam Penelitian. Jakarta: Rajawali Pers.

Kastner, Margit and Stangl, Barbara. (2010). Multiple Choice and Constructed Response Tests: Do Test Format and Scoring Matter 
? International Conference on Education and Educational Psychology (ICEEPSY 2010). Procedia Social and Behavorial Science I2(20II) PP. 263-273. www.science direct.com.

KAYA, Ebru \& Geban Ömer. (20I2). Facilitating Conceptual Change in Rate of Reaction Concepts Using Conceptual Change Oriented Instruction, Education and Science Vol. 37, No 163.

Kirik, Özgecan Taștan and Boz, Yezdan. (20I2). Cooperative Learning Instruction for Conceptual Change in the Concept of Chemical kinetics. Chemistry Education and Research and Practice, 13: pp. 221-236. https://www.researchgate.net/publication/2 55755833.

Kolomuç, Ali and Tekin, Seher. (201I). Chemistry Teachers' Misconceptions concerning concept of chemical reaction rate, Eurasian Journal of Physics and Chemistry Education.

Kurz, Terri Barber. (1999). Document Resume, Paper presented at the Annual Meeting of the Southwest Educational Research Association (San Antonio, TX, January 2123, 1999).

Lesage, Ellen., Valcke, Martin, dan Sabbe, Ellien. (20I3). Scoring Method for Multiple Choice assessment in Higher Education - is it still a matter of number Right Scoring or Negative Marking?, Studies in Educational Evaluation 39: PP. I88-189. Journal homepage: www.elsevier.com/stueduc.

Nbina, Jacoson \& Barineka, Viko, B. (2010). Effect of instruction in Metacognitive selfassessment strategy on Chemistry Students self-efficacy and achievement Academi Arena 2(II): Pp. I-I0 http://www.Sciencepub.net.

Nitko, Anthony. J. (2001). Educational Assessment of Students, Prantice Hall Inc.
Noorhadi dan Masruri, Muhsinatun Siasah. (20I4). Perbedaan Keefktifan Model STAD, Jigsaw, dan TGT dalam Meningkatkan Keaktifan dan Hasil Belajar siswa dalam pembelajaran Geografi di SMAN I Kretek, Bambang Lipuro, SMAN I Sandes Kabupaten Bantul, Journal Universitas Negeri Yogyakarta (Geo Educasia -SI) III(II).

Manitoba Education, Citizenship and Youth. (2006). Rethinking Classroom Assessment with Purpose in Mind: Assessment for Learning, Assessment as Learning, Assessment of Learning.

Menteri Pendidikan dan kebudayaan Republik Indonesia. (20/3). Peraturan Menteri Pendidikan dan Kebudayaan Republik Indonesia Nomor 70 Tahun 2013 tentang kerangka dasar dan struktur kurikulum Sekolah Menengah Kejuruan/madrasah aliyah kejuruan pasal I ayat 2 .

Menteri Pendidikan dan Kebudayaan Republik Indonesia Nomor 60 Tahun 2014 Tentang Kurikulum Tahun 2013 Sekolah Menengah Kejuruan/Madrasah Aliyah Kejuruan.

Mulyono, Eko. (20/3). The Comparation of Reading Comprehension Taught by using STAD and Jigsaw Technique at different motivation to read at the even semester of eleventh Grades in SMAN I Rumbla academic year 2012/2013. Universitas Muhamadiyah Surakarta.

Performance at TIMSS 201I International Benchmarks. TIMSS \& PIRLS International Study Center.

PISA 2015 Results (Volume I) Excellence and Equity in Education, OECD.

PISA Released Items Science (2006) Document: Released PISA Items_Science. Doc. OECD 
PISA Programme for International Student Assessment.

Prihoda, Thomas J et al. (2006). Correcting for Guessing Increases Validity in MultipleChoice Examinations in an Oral and Maxillofacial Pathology Course, Journal of Dental Educationn Volume 70, Number 4.

Rica, Franciska dan Suyanta. (2013). Analisis Kesulitan Belajar Peserta Dididk Dalam Memahami Materi Kelas XI SemesterI SMA Negeri I Sanggau Ledo Kabupaten Bengkayang Tahun Ajaran 2012/20I3. Journal UNY - Pendidikan Kimia - SI - IV, Vol.II, Agustus -September.

http://journal.student.uny.ac.id/jurnal/artikel/478/4 $\underline{9 / 427 .}$

Ristiyani, Erika, dan Bahriah, Evi Sapinatul. (2016). Analisis kesulitan Belajar Kimia siswa SMAN X Kota Tangerang Selatan., journal untirta.ac. id/index php/JPPI/artikel download/43I/pdf- 22(I): pp. 18-29.

Sani, Usman Tunga. (20/5). Effect of Cooperative Learning Strategy on Senior Secondary School Students' Performance in Quantitative Chemistry in Kebbi State, Nigeria. Journal of Education and Science ISSN XXXX- XXXX, I.

Santrock, John W. (2009). Psikologi Pendidikan diterjemahkan oleh Diana Angelica. Jakarta: Salemba Humanika.

Seçken, Nilgün and Seyhan, Hatice Günjör. (20I5). An analysis of high school student' achievement and anxiety over graphical chemistry problem about the rate of reaction Procedia-Social and Behavioral Science I 74 (20I5), pp. 347-354.

Slavin, Robert E. (1987). Cooperative Learning: Student Teams. What Research Says to the Teacher National Education Association, Washington, D.C Document Resume.
Slavin, Robert. E. (1995). Research on Cooperative Learning Achievement: What We Know, What We Need to Know Center for research on the Education of Students Placed at Risk John Hopkins University.

Slavin, Robert E. (2008). Cooperative Learning, Success for All, and Evidence-based Reform in education", Education et didactique 2(2): pp. 152. http://www.revues.org.

Slavin, Robert E. (20II). Psikologi Pendidikan Teori dan Praktik, diterjemahkan oleh Marianto Samosir, Jakarta: PT Indeks.

Sozbilir, Mustafa. (2010). Prospective Chemistry Teachers' Conception of Chemical Thermodynamics and Kinetics., Eurasia Journal of Mathematics, Science \& Technology Education 6(2), Pp. I I I-I 20.

Tsay, Mina and Brady, Miranda. (20l0). A case study of cooperative learning and communication pedagogy: Does working in teams make a difference? Journal of the scholarship of Teaching and Learning, I0(2), pp. 78-89.

Ubulom, William. J and Amini, Clifford. M. (20I2). Determining the effect of Guessing on Tests Scores. Mathematical Theory and Modeling ISSN 2224-804 (paper) ISSN2225-0522 (online) 2 (12): www.iiste.org

Van Driel, Jan. H. (2002). Students' Corpuscular Conceptions in the Context of Chemical Equilibrium and Chemical Kinetics. Chemistry Education: Research and Practice in Europe Vol. 3, No.2, pp. 20I-2I3.

Vygotsky. (1978). The Development of Higher Psyhological Processes. Harvard University Press.

Webb, Noreen. M (1982). Student Interaction and Learning in Small Group, Review of 
Educational Research 1982; 52; 421 http://www.sagepublications.com.

Webb, Noreen; Nemer, Kariane; Chizhik, Alex; Sugrue, Brenda. (1997). Equity Issues in Collaborative Group assessment: Group Composition and Performance. National Center for Research on Evaluation (CRESST) Graduate School of Education \& Information Studies University of California, Los Angeles.

Winkel, W. S, Psikologi Pengajaran. Yogyakarta: Media Abadi, 2004.

Woolfolk, Anita. (2009). Educational Psychology Active Learning Edition, (terjemahan Helly Prajitno Soecipto dan Sri Mulyantini Soecipto Jakarta: Pustaka Pelajar.

Yen, Yung-Chin et al. (2010). Development and Evaluation of a Confidence-Weighting Computerized Adaptive Testing, International Forum of Educational Technology \& Society (IFETS), I 3 (3): 163I76 ISSN I436-4522 (online) and II763647 (print)

Yeung, Hastings Chim Ho. (20I5). Literature Review of The Cooperative Learning Strategy-Student Team Achievement Division STAD), International Journal of Education ISSN 1948-5476., 7(I): pp. 2943. http://dx.doi.org / $0.5296 /$ ije.v7il.6629.

Zoller, U. (1993). Are Lecture and learning compatible. Symposium: Lecture and Learning. 